\title{
Author Correction: RNA synthesis is modulated by G-quadruplex formation in Hepatitis $C$ virus negative RNA strand
}

\author{
Chloé Jaubert ${ }^{1}$, Amina Bedrat ${ }^{2}$, Laura Bartolucci ${ }^{2}$, Carmelo Di Primo ${ }^{2}$, Michel Ventura ${ }^{1}$, \\ Jean-Louis Mergny $\mathbb{D}^{2,3}$, Samir Amrane ${ }^{2}$ \& Marie-Line Andreola ${ }^{1}$
}

Correction to: Scientific Reports https://doi.org/10.1038/s41598-018-26582-3, published online 25 May 2018

The original version of this Article contained errors in the spelling of the authors Chloé Jaubert, Amina Bedrat, Laura Bartolucci, Carmelo Di Primo, Michel Ventura, Jean-Louis Mergny, Samir Amrane and Marie-Line Andreola which were incorrectly given as Jaubert Chloé, Bedrat Amina, Bartolucci Laura, Di Primo Carmelo, Ventura Michel, Mergny Jean-Louis, Amrane Samir and Andreola Marie-Line respectively.

These errors have now been corrected in the PDF and HTML versions of the Article, and in the accompanying Supplementary Information File.

(i) Open Access This article is licensed under a Creative Commons Attribution 4.0 International License, which permits use, sharing, adaptation, distribution and reproduction in any medium or format, as long as you give appropriate credit to the original author(s) and the source, provide a link to the Creative Commons license, and indicate if changes were made. The images or other third party material in this article are included in the article's Creative Commons license, unless indicated otherwise in a credit line to the material. If material is not included in the article's Creative Commons license and your intended use is not permitted by statutory regulation or exceeds the permitted use, you will need to obtain permission directly from the copyright holder. To view a copy of this license, visit http://creativecommons.org/licenses/by/4.0/.

(C) The Author(s) 2019

${ }^{1}$ Univ Bordeaux, CNRS UMR5234, MFP laboratory, F-33000, Bordeaux, France. ${ }^{2}$ Univ Bordeaux, ARNA laboratory, INSERM U1212, CNRS UMR 5320, IECB, F-33600, Pessac, France. Institute of Biophysics, Academy of Sciences of the Czech Republic, 612 65, Brno, Czech Republic. Correspondence and requests for materials should be addressed to C.J. (email: jaubert.chloe@gmail.com) or M.-L.A. (email: marie-line.andreola@u-bordeaux.fr) 